\title{
СТИМУЛЮВАННЯ ІНТЕРЕСУ СТУДЕНТІВ ЕКОНОМІЧНИХ СПЕЦІАЛЬНОСТЕЙ ДО ВИВЧЕННЯ ІНОЗЕМНОЇ МОВИ
}

\author{
У статті обтрунтовано доиільність звернення до мотивачійної сфери студентів через запровадження спеиіальних \\ методів задля стимулювання стійкого пізнавального інтересу до навчання іноземної мови. \\ Ключові слова: мотивачія, мотив, іноземна мова, мотивачійний етап, внутрішня мотивація.
}

В статье обоснована иелесообразность обращения к мотивационной сфере студентов с использованием специальных методов для стимулирования стойкого познавательного интереса к изучению иностранного языка.

Ключевые слова: мотивачия, мотив, иностранный язык, мотиваџионный этап, внутренняя мотиваџия

The article grounds expediency of apply to students' motivational sphere through specific methods for stimulation of steady cognitive interest to learning foreign language.

Key words: motivation, motive, foreign language, motivational stage, internal motivation.

Розвиток інтересу студентів до вивчення іноземних мов $\epsilon$, по-перше, могутнім чинником розвивального впливу на особистість; по-друге, засобом удосконалення таких комунікативних умінь як чітке оформлення думки, формулювання запитання, ведення діалогу; по-третє, потужним джерелом нової соціокультурної інформації, яка потребує з боку студента постійного аналізу, порівняння, оцінювання тощо. Поєднання цих трьох чинників зумовлює суттєві можливості іноземної мови у формуванні мислення студента. Уміння реалізувати такий виховний потенціал іноземної мови у навчанні студентів залежить значною мірою від урахування вчителем індивідуальних психологічних i вікових особливостей студентів, володіння педагогічними закономірностями і дидактичними прийомами формування мислення. А також мотиваційний етап навчання іноземної мови у ВНЗ неодмінно спрямований на стимулювання пізнавального інтересу студентів у процесі підготовки до майбутньої професійної діяльності та подолання труднощів, пов'язаних із специфікою навчання іноземної мови й підготовки до участі в нестандартних ситуаціях професійного спілкування. Оскільки мотивація є особистісним утворенням, то процес мотивування, щоб бути ефективним, має проходити через інтереси, бажання, потреби, мотиви і нахили суб'єктів навчання до певного способу опрацювання навчального матеріалу.

Meта cmammi - закцентувати увагу викладача вищого економічного навчального закладу на стимуляції пізнавального інтересу студентів до навчання іноземної мови методами мотивації.

У філософському відношенні мотиви як своєрідні стимули до діяльності тісно взаємопов'язані 3 метою. Як брак людини у будь-чому, вважав О. Леонтьєв, мотив стає фактором, що спрямовує та регулює діяльність тільки в тому випадку, якщо здійснюється іiі «зустріч» 3 предметом задоволення [3].

Практичне значення мотиваційного етапу полягає в забезпеченні активного зацікавленого прагнення студентів до участі в навчальній діяльності. Для того, щоб навчання іноземної мови було дійсно ефективним, у студента повинен виникнути інтерес на рівні внутрішньої потреби у знаннях, уміннях та навичках, що пропонує викладач, а також потяг активно діяти в напрямку їх отримання [9].

Стимулювання інтересу на мотиваційному етапі навчання великою мірою залежить від уміння викладача створити позитивні переживання, пов'язані 3 тим, що супроводжує засвоєння даного предмету, розділу, теми, сформувати емоційно-позитивне ставлення до навчання. Пізнавальний інтерес не втрачає своєї важливої ролі на будь-яких вікових рівнях, навіть для дорослих. Велику роль у цьому процесі до навчання відіграє особистість викладача, його знання, майстерність, обізнаність 3 широкого кола питань, захоплення своєю справою, доброзичливе ставлення до студентів, небайдужість до їх успіхів.

Важливо створювати диференційні й індивідуалізовані програми навчання. Поєднання усіх форм роботи: індивідуальної, самостійної, парної, групової $\epsilon$ важливим засобом підвищення якості навчання і виховання студентів, дозволяє краще враховувати їхні індивідуальні відмінності, сферу інтересів. Ураховування індивідуальних особливостей студентів сприяє досягненню запланованого результату. Навчання робить активним більш широке впровадження елементів самонавчання і взаємопов'язаного навчання. Надзвичайно перспективними $є$ ідеї створення навчальних програм 3 використанням комп'ютерів і відеозаписів, і впровадження їх у практику ВНЗ. Інтенсифікація навчання як одна 3 важливих сучасних тенденцій, диктує необхідність модифікувати урок іноземної мови - перетворювати його в урок - екскурсію, в урок - конференцію, урок - телеміст. Особливе значення має вихід в інші практичні види діяльності, у процесі яких відбувається реальне іншомовне спілкування. Такий вихід може здійснюватися: 1) на внутрішньому рівні ВНЗ - під час спілкування 3 іноземними гостями, зустрічах на зразок КВК; 2) у міжрівневій площині ВНЗ - організація 
листування іноземною мовою, олімпіад, фестивалів, тижнів іноземної мови; 3) поза межами ВНЗ - у процесі включення студентів до реальної трудової діяльності.

Очевидно, що запланований результат навчання іноземної мови може бути досягнутий, якщо будуть поліпшені умови навчання і якщо студенти насправді будуть відчувати, що від них реально потрібне практичне володіння іноземною мовою [7, с. 78]. Завдяки високому рівню мотивації у студента формується мета і його навчання стає активним, незалежним від викладача, переходить у саморегульовану діяльність. 3 теоретичної позиції , мотивація навчання - це сукупність усіх процесів, методів, засобів збудження учнів до навчальної діяльності. Під мотивацією навчання також розуміють ступінь готовності суб'єкта наполегливо прагнути досягнення навчальних цілей, що сприймаються як обов'язкові. Влучно помічено І. Підласим, що кермо мотивації тримають одночасно педагоги та учні $[8$, с. 360].

Є. Ільїн уважав, що структура мотиву містить три блоки: 1) блок потреби включає у себе переважання за біологічними, соціальними потребами; 2) блок внутрішнього фільтру включає переважання за внутрішніми чинниками (інтересами, схильностями, ідеалами, цінностями, переконаннями, установками тощо); 3) ціiльовий блок включає ціль, відповідну дію й сам процес задоволення потреби.

На думку вченого, чим більше мотивів у навчанні, тим більшу мотиваційну напругу вони створюють. Сила і стійкість є найважливішими характеристиками мотиву. Сила мотиву виступає показником непереборного прагнення особистості й оцінюється ступенем і глибиною усвідомлення потреби. Сила мотиву визначається як фізіологічним (силою мотиваційного збудження), так i психологічним (знання результатів діяльності, розуміння іiі змісту, свобода творчості) чинниками. Стійкість мотиву оцінюється наявністю його у певних видах діяльності людини, його впливом на поведінку у складних умовах діяльності [6].

Досвід викладання у ВНЗ свідчить, що не завжди викладачі приділяють достатньо уваги цьому важливому аспекту ефективного навчання, i це часто зумовлено недостатнім володінням методами та прийомами мотивації й стимулювання учнів.

Г. Романова виокремлює такі методи мотивації: 1) комунікативна атака (використання ефектної цитати, незвичайної дії; розповідь казки, анекдоту; цікаве запитання; театралізація, особисте зацікавлення викладача, приклад 3 власного життя викладача); 2) доведення до переконання (посилання на негативні або позитивні наслідки незнання чи знання; посилання на несуперечливі факти; посилання на авторитетні джерела в певній галузі; використання аналогій та порівнянь); 3) сугестія (періодичне повторення однієї і тієї ж думки; викликання бажаної емоційної реакції слухачів; інтонаційне підкреслення важливих моментів виступу; автоматичне включення до певної роботи); 4) метод долання перешкод (розв'язання певних навчальних задач, ситуацій, які неможливо розв'язати без вивчення матеріалів теми; стимулювання часом (обмеженість у часі чи нагорода за швидкість); 5) метод делегування (звертання за порадою до аудиторії; гра, конкурс, змагання; спільне планування навчання змісту, форм та методів навчання, контролю); взаємоперевірка; індивідуальний вибір завдань; самоперевірка: участь студентів у створенні навчально-методичної літератури, підручників; 6) метод закріплення позитивного враження (узагальнення основних думок, підбиття підсумків, резюме; комплімент слухачам, подяка; створення гумористичних ситуацій; ефектна цитата; нагнітання та кульмінація - розрядження; «ефект Шахеризади», чи завершення закінчення [9].

Для того, щоб усі перелічені методи зовнішньої мотивації були ефективними, треба, на нашу думку, не менше уваги приділяти внутрішній мотивації. Викладач може цілеспрямовано проводити мотивуючу роботу, але не завжди у студента виникає позитивна установка на сприйняття i осмислення пропонованого навчального матеріалу. Зарадити цьому можна, на думку С. Максименко, за допомогою оптимізації сприйняття і мислення студента [4]. Дослідник дає певні поради: сприйняття має бути повним, інформація, що пропонується, передбачає активне використання наочного матеріалу і ТЗН, опорне конспектування (зоровий аналізатор пропускає до психіки $80 \%$. слуховий $-10 \%$, нюховий, смаковий і тактильний - 10\%). Сприйняття має бути цілісним - мати високий ступінь пов'язаності з когнітивним полем суб'єкта, тобто попереднім досвідом когнітивної діяльності студента, а отже - його навчальним стилем.

Аргументом на користь урахування особливостей сенсорного сприйняття студентів у навчанні їх іноземної мови $є$ той визнаний у психології факт, що активація одного або декількох базових почуттів - зору, слуху, дотику, нюху, смаку - передбачає встановлення стійкої мотивації і навпаки.

Як стверджує К. Ізард, цей процес має зворотній характер [2, с. 23]. Так само достатня мотивація, за визначенням Ж. Піаже і П. Фресса як «порогова емоція» може загострити сприйнятливість провідних сенсорних регістрів. Установлено, що емоція, мобілізуючи енергію, керує мисленнєвою і фізичною активністю індивіда, направляє іï у певному руслі, фільтрує наше сприйняття, встановлюючи сенсорний зворотній зв'язок. Емоція є свого роду організуючою силою свідомості, яка впорядковує і творчо реорганізує інформацію, що надходить від рецепторів [2, с. 88].

Принциповим для розуміння природи мотивації діяльності $\epsilon$ визначення В. Стрельнікова. Дослідник розглядає ііі як прагнення людини виявити себе в тому, до чого вона відчуває себе 
потенційно здібною, як генетичне прагнення людини до самореалізації згідно з ії природними здібностями до певних видів діяльності і наполегливість в оволодінні нею на творчому рівні [10].

У процесі підготовки студентів як майбутніх фінансистів чи бухгалтерів дуже важливим $є$ те, щоб у них з'явилася внутрішня мотивація до мовлення іноземною мовою як засобу привласнення соціального досвіду. А для цього, зазначає І. Зимня, мовлення має бути особистісно значущим і особистісно зорієнтованим [1, с. 111]. В. Бухбіндер і Г. Китайгородська висловлюють упевненість, що внутрішня мотивація з'являється у студента, коли він відчуває задоволення (успіх), що з ним спілкуються на його рівні сприйняття і рівні засвоєння знань $[5$, с. 70$]$.

Багато психологів наголошують на багатогранності людської мотиваційної сфери. Процесуальна мотивація пов'язана 3 наявністю актуально діючої потреби в успішному виконанні навчальних дій.Однак сама процесуальна мотивація не в змозі забезпечити високий рівень навчальної діяльності. Для цього потрібна перспективна мотивація, яка грунтується на усвідомленні способів і прийомів ефективної діяльності. Мотиви відносин і справи зливаються в них 3 мотивами мети (для них важливо «для чого робити», «що робити», «як і з ким робити»).

Отже, під час опрацювання різних джерел із проблеми ролі мотивації в навчальному процесі, ми дійшли висновку, що мотиваційний етап навчання іноземної мови має забезпечити не стільки зовнішню, скільки внутрішню процесуальну мотивацію кожному студенту через стимулювання пізнавального інтересу до навчання, упровадження методів, адекватних певним способам опрацювання навчального матеріалу.

\section{Література}

1. Зимняя И. А. Педагогическая психология / И. А. Зимняя. - М. : Логос, 1999. - 384 с. 2. Изард К. Э. Психология эмоций / Изард К. Э.; [пер. с англ.]. - СПб. : Питер, 2000. - 464 с. 3. Леонтьев А. А. Дискуссия о проблеме способностей / А. А. Леонтьев, А. Н. Леонтьев, Б. М. Теплов // Вопросы психологии. - 2003. - №2. С. 5-6. 4. Максименко С. Навчання, що виховує і розвиває / С. Максименко // Психолог. Спецвипуск. Психологія дидактики. - 2004. - (21/22). - С. 3-21. 5. Методика интенсивного обучения иностранным языкам /под ред. В. А. Бухбиндера и Г. А. Китайгородской. - К. : Вища школа, 1988. - 343 с. 6. Мотивация и мотивы / Е. Ильин. - Спб. : Питер, 2003. - 512 с. 7. Настольная книга учителя иностранного языка: [справочнометод. пособие]. - М. : АСТ : Астрель, 2004. - 446 с. 8. Подласый И. П. Педагогика. Новый курс [учебн. для студентов пед. вузов: В 2 кн.] / И. П. Подласый. - М. : ВЛАДОС, 1999. - Кн. 1 : Общие основы в процессе обучения. - 576 с. 9. Романова Г. М. Індивідуально-типологічні та дидактичні чинники результативності самостійної роботи студентів економічних університетів : автореф, дис. на здобуття наук. ступ. кандидата пед. наук / Романова Г. М. - Київський національний економічний університет. - К., 2003.- 20 с. 10. Стрельніков В. Ю. Критерії технологій навчання, орієнтованих на розвиток особистості / В. Ю. Стрельніков // Нові технології навчання. - 2002. - Випуск 35.- С. 243-250. 